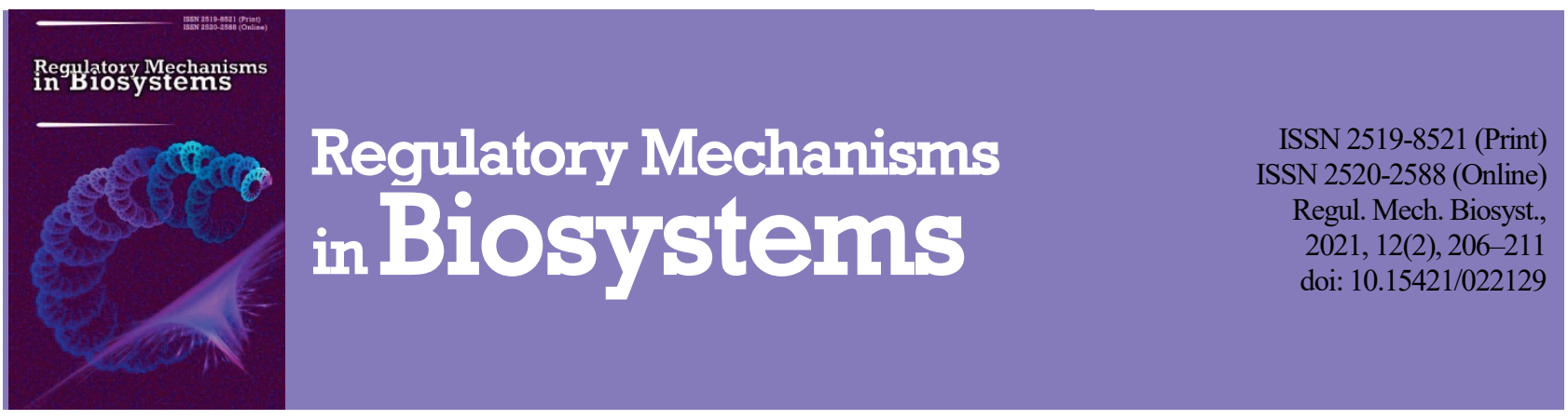

\title{
Dynamics of morphological, immunological and histological changes in microsporia in guinea pigs
}

\author{
Y. V. Kisera, Y. V. Martyniv, B. V. Gutyj \\ Stepan Gzhytskyi National University of Veterinary Medicine and Biotechnologies Lviv, Lviv, Ukraine
}

Article info

Received 17.04.2021

Received in revised form 20.05.2021 Accepted 22.05.2021

\author{
Kisera, Y. V., Martyniv, Y. V., \& Gutyj, B. V. (2021). Dynamics of morphological, immunological and histological changes in \\ microsporia in guinea pigs. Regulatory Mechanisms in Biosystems, 12(2), 206-211. doi:10.15421/022129
}

Stepan Gzhytskyi

National University

of Veterinary Medicine and Biotechnologies Lviv, Pekarska st., 50, Lviv, 79010, Ukraine. Tel.: + 38-068-136-20-54. E-mail:bvh@ukr.net

Microsporia affect different species of animals and humans. The high contagiousness of the pathogen determines the relevance of research into this disease. Microsporum canis is the pathogen that most often causes microsporia. Weakened functions of the immune system and violation of the epithelial barrier of the skin are a favourable factor that causes microspores. The main source of infection is cats, which are involved in the storage and transmission of the pathogen. To clarify the dynamics of morphological, immunological and histological changes in microsporia, blood and skin studies of guinea pigs infected with $M$. canis were carried out. The animals were divided into two groups of 6 guinea pigs (healthy and sick). Test material (blood and skin) was taken from clinically healthy and sick animals 21 and 42 days after infection. The number of erythrocytes and leukocytes was determined by counting them in the Goryaev chamber, the hemoglobin content - by the method of cyanide hemoglobin. The leukogram was derived based on the counting and differentiation of 200 leukocyte cells in blood smears. Material for histological examination (pieces of skin) was fixed in 10-12\% cooled solution of neutral formalin, followed by pouring in paraffin according to the scheme proposed by G. A. Merkulov. The obtained results demonstrated that leukocytosis developed in guinea pigs with microsporia on the 21st and 42nd days; the number of rod-shaped neutrophils increased, that of segmental neutrophils decreased, and that of ESR increased. The immune response to the course of microsporia was manifested in an increase in the percentage of T-lymphocytes, T-suppressors and a decrease in T-helper cells and an increase in T-killers compared with healthy animals. Histological examination showed that on the 21st day after infection, hyphae and spores of the fungus $M$. canis were localized in the skin. There is swelling of the dermis, stratification of collagen fibers and the accumulation of inflammatory infiltrates around the hair follicles. On the 42nd day, the infiltration spread and dystrophic changes in the skin occurred in the form of desquamation of the epidermis and the formation of acanthosis and hyperkeratosis on the surface of the dermis. The conducted research will allow further assessment of the course of microsporia under the action of various drugs and help establish the most effective method of treatment.

Keywords: Microsporum canis; immune system; immune response; hyperkeratosis; leukocytes; neutrophils; lymphocytes.

\section{Introduction}

Skin diseases caused by infectious pathogens are relevant in the work of a veterinarian. Microsporia is referred to diseases of fungal etiology which are the most common in veterinary practice (Bezlushhenko, 2017; Pasquetti et al., 2017; Moriello et al., 2017). Microsporia is a highly contagious disease that affects the skin. The pathogen is dangerous to humans. The causative agent of microsporia is the zoophilic fungus Microsporum canis (Medvedeva et al., 2002; Subelj et al., 2014). The source of infection is cats $(80.5 \%)$, especially kittens $(70-80 \%)$ and dogs in rare cases. They are involved in the preservation and transmission of infection (Novoselov $\&$ Novoselov, 2004). The violation of zoohygienic rules of keeping and feeding animals contributes to the spread of microspores (DeBoer, 2003). In addition, a favourable factor for infection and clinical manifestations of the disease is the immunosuppressive state of the body. Animals which are weakened, sick with other infectious diseases, lactating, old and in the period between vaccinations, are at risk of infection with microsporia (Haitov, 2000). Microsporia occurs as an independent disease and as a complication of other skin diseases (Ascioglu et al., 2002). The skin can be a gateway for fungal infection when the epithelial barrier is broken due to injury or allergic or bacterial dermatitis. Subclinical course of microsporia without visible manifestations on the skin is possible. But at the same time the pathogen is actively spreading in the environment. Infected animals pose a risk of infection to those with whom they come into contact (DeBoer, 2003). That is why they need to be isolated during treatment.
Microsporia is a highly contagious disease that manifests itself in the form of erythema on the skin, the occurrence of local alopecia, dryness and peeling of the skin. The characteristic feature is the absence of itching. Hair is broken or missing; flakes are layered on its surface (Pototskyi, 2000; Cavalcanti et al., 2002). There is a thickening of the skin with signs of hyperkeratosis or dry seborrhea in places of clinical manifestation of the disease (Carlotti, 1997). The incubation period of microspores lasts up to 21 days (Bezlushhenko, 2017). Once the pathogen $M$. canis is on the skin, it is absorbed into it and begins to multiply, affecting different layers. The course of the disease is chronic on the 42nd day after infection (Medvedeva et al., 2002). One can assess the degree of damage to all layers of the skin during this period, examining the blood to characterize the reactivity and immune response of the body during microsporia.

The purpose of this work is to conduct a study of the blood and skin of patients with microsporia in guinea pigs in order to determine body's immune reactivity during microsporia.

\section{Materials and methods}

Clinical and experimental studies were performed in accordance with the requirements of the European Convention for the Protection of Vertebrate Animals used for Experimental and Other Scientific Purposes (Strasbourg, 1986). The experiment complied with the ARRIVE guidelines. And it was conducted in accordance with the UK Animal Science (Scientific Procedures) Act 1986 and the relevant guidelines. 
To determine the body's immune reactivity against microsporia, blood and skin tests of guinea pigs infected with the pathogen Microsporum canis were carried out. Two groups of animals were formed, 6 guinea pigs each (healthy and infected).

Infection occurred when a suspension of the $M$. canis pathogen was applied to a scarred skin area with a sterile blade.

The pathogen suspension was prepared from colonies of $M$. canis cultured on Dermakit environment for up to 10 days at $25^{\circ} \mathrm{C}$. The colonies were carefully scraped from the surface of the culture medium and placed in tubes with a sterile solution of $0.9 \%$ sodium chloride with a volume of $20 \mathrm{~mL}$. A homogeneous suspension was formed by grinding and $0.4 \mathrm{~mL}$ was applied to a $4 \times 4 \mathrm{~cm}$ diameter scarified skin area. The inoculum was adjusted to $10^{6}$ Microsporum canis spores $/ \mathrm{mL}$. The material for testing (blood and skin samples) was taken from clinically healthy animals and from patients on days 21 and 42 after infection.

The research was conducted in the vivarium of Ternopil National Medical University named after I. Gorbachevsky, Ternopil. Hematological and immunological blood tests were performed in the laboratory of the Metropolitan Andriy Sheptytsky Hospital in Lviv. Histological examinations were performed in the laboratory of clinical and biological studies of State Scientific-research Control Institute of Veterinary Medicinal Products and Feed Additives in Lviv. The number of erythrocytes and leukocytes was determined by counting them in the Goryaev chamber, the hemoglobin content by the hemoglobin cyanide method.

The leukogram was derived on the basis of counting and differentiation of 200 leukocyte cells in blood smears stained by the method of Romanovsky-Gimza. This took into account cell size, size and shape of the nucleus, the presence and colour of grains in the cytoplasm. Hematocrit value was determined using hematocrit capillaries by centrifugation in a special centrifuge (10 minutes at $3000 \mathrm{rpm}$ ), erythrocyte sedimentation rate (for 1 hour) - using Panchenkov pipettes (Vlislo, 2012).

The T- and B-lymphocytes were counted using the erythrocyte diagnosticum of Ltd "Granum Laboratory", Kharkiv. The principle of the method is based on the determination of subpopulations of T- and Blymphocytes by the reaction of rosette formation with erythrocytes, on which adsorbed monoclonal antibodies against the receptors of $\mathrm{CD} 3$ (Tlymphocytes), CD4 (T-helpers), CD8 (T-suppressors), CD19 or (B-lymphocytes), CD16 (natural killers). The results of the study were recorded in a light microscope with an immersion system.

Material for histological examination (pieces of skin) was fixed in $10-12 \%$ cooled solution of neutral formalin, followed by pouring in paraffin according to the scheme proposed by Merkulov (1969). The fixed pieces with a thickness of $2 \mathrm{~mm}$ were washed in water for no less than 30 minutes, then dried on filter paper and passed through alcohols $(75,96$ and $100^{\circ}$ for dehydration and degreasing in each of the alcohols). Then they were impregnated with a solvent of paraffin xylene for 1.5 hours. The xylene pieces were transferred to a saturated solution of paraffin in xylene for 1.5 hours at a temperature of $37^{\circ} \mathrm{C}$. Then the pieces were kept in molten paraffin at a temperature of $54-55^{\circ} \mathrm{C}$, i.e. at a temperature $2-3^{\circ}$ higher than the melting point of paraffin, up to 2 hours in the first portion of paraffin and up to 2 hours in the second. Then they were transferred to porcelain cups and filled with molten paraffin, followed by rapid cooling in a refrigerator. After the paraffin had hardened, the pieces were cut with paraffin and glued to wooden cubes. Histosections with a thickness of 5 $7 \mu \mathrm{m}$ were made on a sled microtome MS-2. Hematoxylin and eosin staining were used for morphological evaluation of cells and tissues. Microscopy was performed using an Olimpus CX-41 microscope.

Data analysis was performed using Statistica 6.0 (StatSoft Inc., USA). The data are presented in the tables as $\mathrm{x} \pm \mathrm{SD}$ ( $\mathrm{x} \pm$ standard deviation). Differences between values in the control and experimental groups were determined using ANOVA, where the differences were considered significant at $\mathrm{P}<0.05$ (taking into account the Bonferroni correction).

\section{Results}

The hematological results that were obtained showed that guinea pigs with microsporia were characterized by changes in the morphological composition of the blood (Table 1). There were signs of leukocytosis, lymphocytosis on the 21st and 42 nd days after infection. The number of leu- kocytes probably increased to $11.1310^{9} / \mathrm{L}$ from $5.7710^{9} / \mathrm{L}$ in healthy animals. The content of lymphocytes increased in healthy animals to $15.8 \%$ by the 42 nd day after infection. The content was $46.0 \%$ to $65.2 \%$ on the 42 nd day after infection $(\mathrm{P}<0.001)$. The probable increase in the content of rod-shaped neutrophils from $6.3 \%$ in segmental neutrophils decreased from $38.8 \%$ to $12.2 \%$ by the 42 nd day after infection $(\mathrm{P}<$ 0.001). There was a probable increase in ESR from 1.67 to $5.67 \mathrm{~mm} / \mathrm{h}$ on the 42nd day after infection.

Table 1

Morphological parameters of blood

in guinea pigs with microsporia $(x \pm S D, n=6)$

\begin{tabular}{lccc}
\hline \multirow{2}{*}{ Index } & \multirow{2}{*}{ Control } & \multicolumn{2}{c}{ Experimental group } \\
\cline { 3 - 4 } & & 21st day & 42nd day \\
\hline Erythrocytes, $10^{12} / \mathrm{L}$ & $5.65 \pm 0.20$ & $5.53 \pm 0.24$ & $5.25 \pm 0.21$ \\
Hemoglobin, $\mathrm{g} / \mathrm{L}$ & $117.2 \pm 2.9$ & $117.2 \pm 2.1$ & $113.3 \pm 4.5$ \\
Hematocrit, \% & $39.67 \pm 1.15$ & $38.83 \pm 1.19$ & $37.17 \pm 7.60$ \\
Platelets, $10^{9} / \mathrm{L}$ & $210.2 \pm 0.4$ & $223.8 \pm 7.9$ & $231.2 \pm 7.6$ \\
Leukocytes, $10^{9} / \mathrm{L}$ & $5.77 \pm 0.37$ & $8.19 \pm 0.35^{* * *}$ & $11.13 \pm 0,72^{* * *}$ \\
Rod-shaped neutrophils, \% & $6.33 \pm 0.71$ & $13.67 \pm 1.20^{* *}$ & $15.76 \pm 1,29^{* * *}$ \\
Segmental neutrophils, \% & $38.83 \pm 1.30$ & $14.50 \pm 1.95^{* * *}$ & $12.17 \pm 1.47^{* * *}$ \\
Eosinophils, \% & $3.17 \pm 0.40$ & $3.50 \pm 0.43$ & $2.70 \pm 0.73$ \\
Basophils, \% & 0 & 0 & 0 \\
Monocytes, \% & $5.67 \pm 0.49$ & $8.67 \pm 0.56$ & $4.17 \pm 0.83$ \\
Lymphocytes, \% & $46.00 \pm 0.89$ & $59.66 \pm 0.88^{* * *}$ & $65.20 \pm 1.48^{* * *}$ \\
ESR, mmhour & $1.67 \pm 0.21$ & $4.17 \pm 0.31^{* * * *}$ & $5.67 \pm 0.67^{* * *}$ \\
Color indicator & $0.78 \pm 0.01$ & $0.78 \pm 0.01$ & $0.76 \pm 0.02$ \\
\hline
\end{tabular}

Note: in this and the following tables statistically reliable differences were considered compared with the control group: ${ }^{*}-\mathrm{P}<0.05 ;{ }^{*}-\mathrm{P}<0.01$; ${ }^{* * *}-\mathrm{P}<0.001$.

On the 21st and 42nd days after infection in guinea pigs, an increase in T-lymphocytes from $53.0 \%$ to $59.8 \%$ was noticed as well as T-suppressors from $20.8 \%$ to $23.0 \%$, decrease in T-helpers from $40.2 \%$. An increase in T-killers on the 21 st day from $17.5 \%$ to $33.3 \%(\mathrm{P}<0.001)$ was noted compared with healthy animals post-infection compared with healthy guinea pigs (Table 2).

\section{Table 2}

Immunological parameters of blood in guinea pigs with microsporia $(x \pm S D, n=6)$

\begin{tabular}{lclc}
\hline \multirow{2}{*}{ Index } & \multirow{2}{*}{ Control } & \multicolumn{2}{c}{ Experimental group } \\
\cline { 3 - 4 } & & \multicolumn{1}{c}{ 21st day } & 42nd day \\
\hline B-lymphocytes, \% & $21.50 \pm 1.06$ & $20.83 \pm 1.11$ & $22.33 \pm 0.95$ \\
T-lymphocytes, \% & $53.00 \pm 1.53$ & $59.83 \pm 1.50^{* *}$ & $53.83 \pm 0.85$ \\
0-lymphocytes, \% & $23.50 \pm 2.17$ & $19.34 \pm 1.41$ & $23.84 \pm 1.14$ \\
Natural killers, \% & $17.50 \pm 0.85$ & $22.67 \pm 1.50$ & $19.33 \pm 0.84$ \\
T-helpers, \% & $40.17 \pm 1.17$ & $35.00 \pm 1.21^{*}$ & $33.33 \pm 0.71^{* * *}$ \\
T-suppressors, \% & $20.83 \pm 0.91$ & $21.50 \pm 1.26$ & $23.00 \pm 1.51^{*}$ \\
\hline
\end{tabular}

The structure of the skin layers is preserved during the course of microsporia. There are inflammatory processes in the epidermis, dermis and hypodermis. Histological examination of the skin at the 21st day after infection revealed the presence of spores and hyphae of the pathogen Microsporum canis in the stratum corneum and hair follicles (Fig. 1).

Inflammatory infiltration had increased by the 42 nd day after infection. This was manifested by an increase in the volume of accumulated infiltrate in the skin around the hair follicles (Fig. 2). Dystrophic changes in the epidermis developed, which was manifested in the form of desquamation and the formation of acanthosis and hyperkeratosis on the surface of the dermis.

\section{Discussion}

Changes in the blood during the course of microsporia indicate that the leukocytosis develops in the body, which is peculiar to inflammatory and infectious diseases, when the body intensively produces new leukocytes to fight the pathological agent (Smith, 1947). Lymphocytosis in microbial infections is peculiar to the second half of the immune response, which occurs after successful transmission of antigen information to lymphocytes from antigen-presenting cells (macrophages, dendritic cells) (Joyner, 1938; Ascioglu et al., 2002; Zimmerman et al., 2015). Suppression of displays of inflammation is noted at the transition of the immune 
response to a lymphocytic phase in a clinical situation. This occurs on the background of an increase in the level of lymphocytes, which is explained by the functional purpose of immunocompetent cells (Haitov, 2000; Ya- kobysiak, 2004). There is a neutrophilic shift of the nucleus to the left, which is observed in chronic inflammatory processes and in depleted animals. Increased ESR indicates an inflammatory process, i.e. delayed infection.
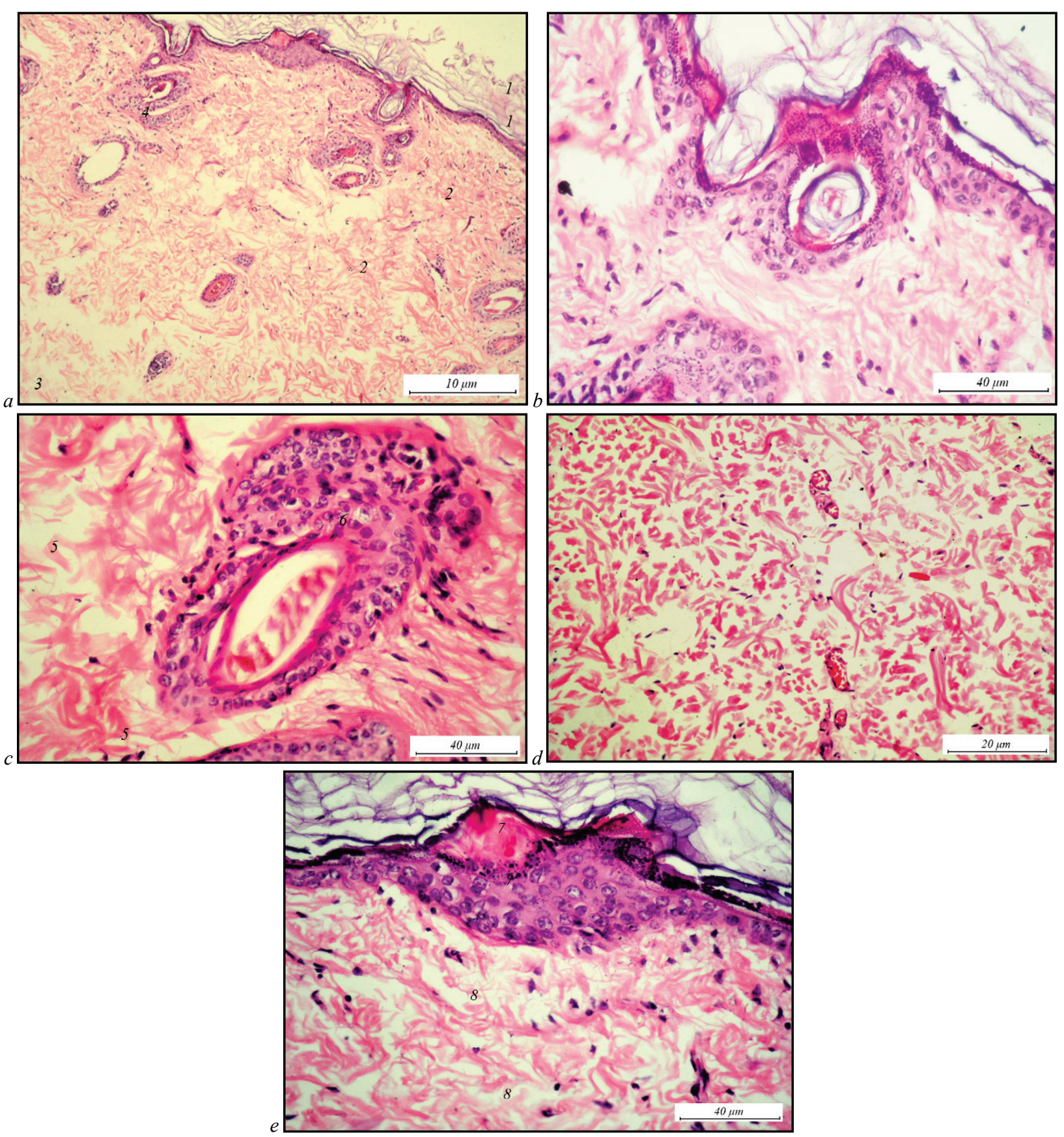

Fig. 1. Histological structure of guinea pig skin on the 21th day after infection: $a$ - structure of guinea pig skin; $b$-the presence of spores and hyphae of $M$. canis in the stratum corneum and hair follicles; $c$-histological changes of dermal fibers and hair follicle; $d$-congestive hyperemia of blood vessels;

$e$-hyperplasia of the epidermis and formation of a cystic cavity, edema of the dermis: 1 -epidermis; 2 -dermis; 3 -hypodermis; 4 -hair follicles;

5 - stratification of dermal fibers; 6 - inflammatory infiltrates around the hair follicle; 7 -hyperplasia of the epidermis; 8 -formation of a cystic cavity, edema of the dermis; staining using hematoxylin and eosin

The number of T-helpers decreases in bacterial and fungal infections of chronic, long-term course (Budumjan \& Panova, 2003). T-helpers recognize the antigen, interact with B-lymphocytes and promote their transformation into plasma cells.

They are the main engine in immune responses; help B-lymphocytes in immune responses to T-cell-dependent agents. The number of T-lymphocytes at the beginning of the disease may increase with immune activation, which is caused by infection (Barlov, 1994). T-suppressors provide the formation of immunological tolerance and inhibit the excessive activity of T- and B-lymphocytes, thereby preventing an excessive immune response. Histological studies have shown that in a healthy guinea pig the epidermis is represented by a multilayered squamous corneal epithelium. The basal layer is preserved and consists of cylindrical cells. The prickly, granular and horny layer which is formed by horny scales is well visible. The dermis is represented by bundles of elastic and collagen fibers with the presence of histiocytes, fibroblasts (Fig. 3), built of papillary and reticular (reticular) layers. Collagen fibers are collected in bundles of different shapes and thicknesses. Layers of loose fine-fiber fabric are placed in separate bundles. The hypodermis is represented by loose connective tissue between the bundles of which are fibroblasts, histiocytes and fat cells, which when stained are determined in the form of transparent honeycomb structures (Kisera et al., 2020). 

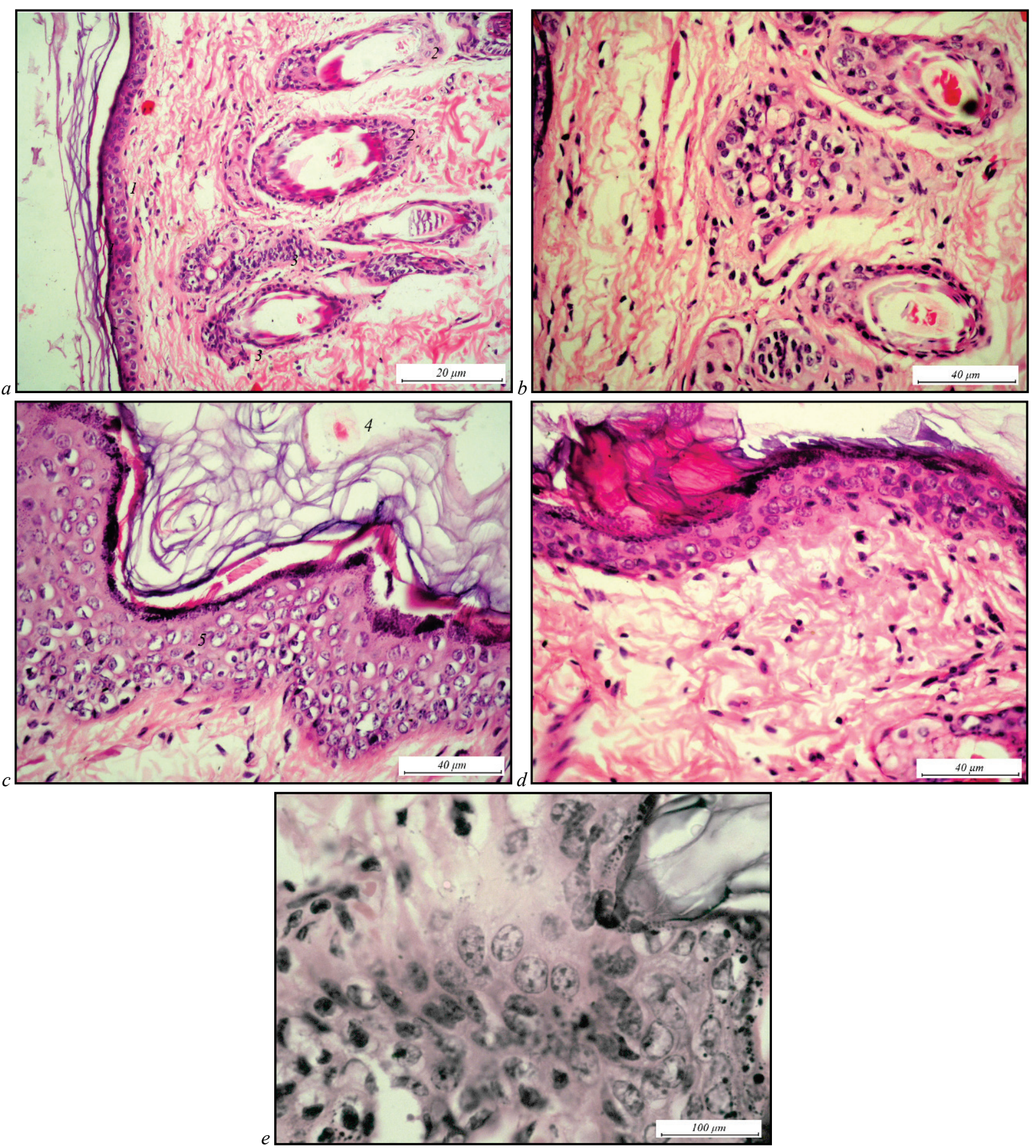

Fig. 2. Histological structure of guinea pig skin on the 42 nd day after infection: $a$-histological changes around the hair follicles; $b$-lymphohistiocytic infiltrates of the dermis; $c$ - histological changes of the epidermis; $d$-desquamation of the homy cells of the epidermis; $e$-hyperplasia of the cells of the basal layer, spinous cells of the epidermis: 1 - epidermis; 2 - hair follicles; 3 - the presence of inflammatory infiltrates around the hair follicles;

4 -hyperkeratosis, acanthosis, thickening of the stratum corneum; 5 -hyperplasia of basal layer cells; staining using hematoxylin and eosin

Stratification of the dermis fibers at the 21 st day after infection due to the course of inflammation occurs; there is an accumulation of inflammatory infiltrates around the hair follicles (Fig. 1). Neutrophilic infiltrate occurs when skin is infected with an infectious agent, where neutrophils and histiocytes act as an inflammatory mediator. An inflammatory reaction in the thickness of the skin causes swelling of the dermis. Swelling of the dermis and stratification of collagen fibers provokes the appearance of congestive hyperemia of blood vessels (Fig. 1), which macroscopically manifests itself in the form of erythema on the skin surface in ill animals. Congestive hyperemia in blood vessels leads to circulatory disorders in the microcirculatory tract. The consequence of this process is damage to the trophic skin in general and its individual structures in particular. Due to malnutrition, the epidermis undergoes dystrophic changes in the form of hyperplasia. There are concomitant pathomorphological changes, which manifest themselves in the form of cystic cavities, which thin the skin surface and as a result facilitate its trauma, which can provoke secondary infection with secondary flora and the formation of microabscesses (Fig. 1), leading to reduced or partial loss of barrier skin functions in the affected areas (Horalskyi et al., 2005; El-Dessouky et al., 2019). Inflammatory infiltration increases at the 42 nd day after infection. This is manifested by an increase in the volume of accumulated infiltrate in the skin around the hair follicles (Fig. 2).

Concomitantly, there is a thickening of the dermis due to edema and its defeat by histiocytic infiltrates (Fig. 2). The stratum corneum of the epidermis thickens due to hyperkeratosis. Proliferation of cells of the spinous layer and an increase in the number of their rows, as well as the penetration of epithelial papillae into the papillary layer of the dermis is a sign of acanthosis. Dystrophic changes become more obvious and mani- 
fest themselves in the form of hyperplasia of the cells of the basal layer (Fig. 2). There is peeling of the horny cells of the epidermis (desquamation). Macroscopically, this manifests itself through formation of scales on the skin surface or the appearance of dry seborrhea. The dermis is swollen, on the surface of the epidermis - hyperkeratosis (Fig. 2). The increase in cells of epidermis, the hyperplasia of cells of the basal layer, spinous cells is noted (Fig. 2). These changes indicate the occurrence of dystrophy due to prolonged exposure to a pathogenic agent in the chronic course of microsporia, which can lead to scleroderma.
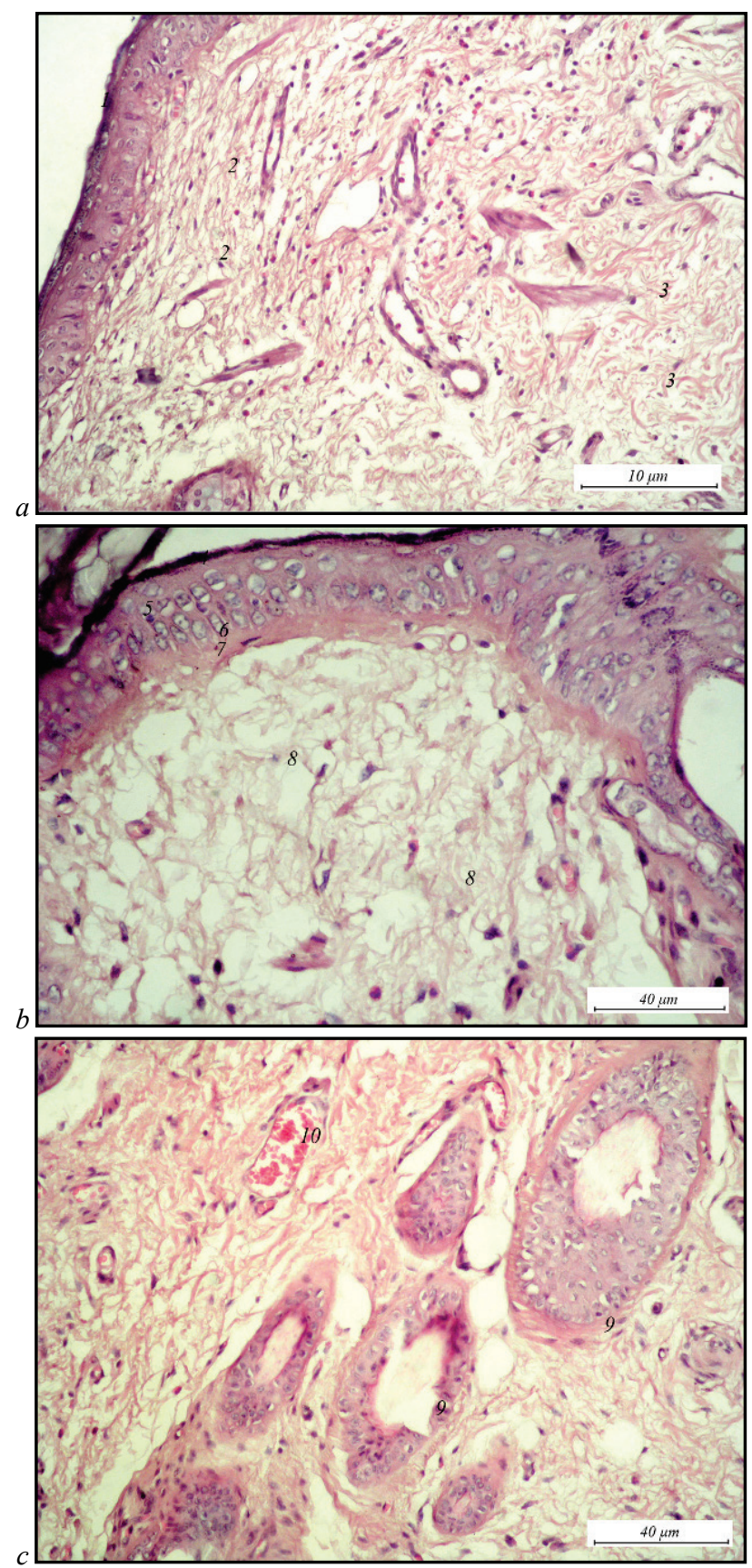

Fig. 3. Skin of a healthy guinea pig: $a$ - layers of the skin; $b$ - layers of the epidermis; $c$-derma of a healthy guinea pig: 1 - epidermis;

2 - actual skin; 3 - subcutaneous fat; 4 - stratum corneum; 5 - granular layer; 6 - prickly layer; 7 -basement membrane; 8 -actually derma;

9-hair follicles; 10 - blood vessels; staining using hematoxylin and eosin

There are constant inflammatory reactions that lead to dystrophic changes that can be irreversible with a long course of microsporia in the skin. The layers of the skin become thinner, which increases the perfusion of the dermis. As a result, the course of microsporia may be complicated by secondary bacterial pioderma.

\section{Conclusion}

Changes in the morphological composition of blood in guinea pigs with microsporia at the 21st and 42nd days after infection were characterized by leukocytosis, lymphocytosis, neutrophilic shift of the nucleus to the left. The immune response was characterized by an increase in Tlymphocytes, T-helpers and a decrease in T-suppressors.

On the 21st day after infection, hyphae and spores of the fungus M. canis were localized in the skin, which caused an inflammatory process characterized by swelling of the dermis, stratification of collagen fibers and the accumulation of inflammatory infiltrates around the hair follicles. By the 42nd day, the infiltration had spread and dystrophic changes in the skin occurred in the form of desquamation of the epidermis and the formation of acanthosis and hyperkeratosis on the surface of the dermis.

\section{References}

Ascioglu, S., Rex, J. H., de Pauw, B., Bennett, J. E., Bille, J., Crokaert, F., Denning, D. W., Donnelly, J. P., Edwards, J. E., Erjavec, Z., Fiere, D., Lortholary, O., Maertens, J., Meis, J. F., Patterson, T. F., Ritter, J., Selleslag, D., Shah, P. M. Stevens, D. A., \& Walsh, T. J. (2002). Defining opportunistic invasive fungal infections in immunocompromised patients with cancer and hematopoietic stem cell transplants: An international consensus. Clinical Infectious Diseases, 34(1), 7-14.

Barlov, Y. (1994). T lymphocytes and immunosuppression in the burned patient: A review. Burns, 20(6), 487-490.

Bezlushhenko, O. V. (2017). Mikrosporija u koshek [Microsporia in cats]. Mir Veterinarii, 5, 26-28 (in Russian).

Budumjan, T. M., \& Panova, E. O. (2003). Etiologija i lechenije zooantropoznoj mikrosporii [Etiology and treatment of zooanthroponous microsporia]. Rossijskij Zhumal Kozhnyh i Venericheskih Boleznej, 6, 33-35 (in Russian).

Carlotti, D. N. (1997). Canine and feline superficial fungal skin infections. Veterinary Quarterly, 19(1), 45-46.

Cavalcanti, J. N., Guerra, J. L., Gambale, W., Corrêa, B., \& Paula, C. R. (2002). Histopathologic and mycologic aspects of experimental infection of guinea pigs with Microsporum canis. Brazilian Journal of Veterinary Research and Animal Science, 39(5), 238-243.

de Hoog, G. S., Guarro, J., Gene, J., \& Figueras, M. J. (2000). Atlas of clinical fungi. 2nd edition. Universitet Rovire I Virgili, Reus.

DeBoer, D. J. (2003). Effects of lufenuron treatment in cats on the establishment and course of Microsporum canis infection following exposure to infected cats. Journal of the American Veterinary Medical Association, 222(9), 1216-1220.

El-Dessouky, Y. M. M., El-Dessouky, M. M., \& El-Batrawy, O. A. (2019). Penicillamine as radiation protector against gamma radiation effect on complete blood count parameters of guinea pigs. Al-Azhar Assiut Medical Journal, $17(2), 145-153$.

Haitov, R. M. (2000). Fiziologija immunnoj sistemy [Physiology of the immune system]. Rosijskij Fiziologicheskij Zhumal imeni I. M. Sechenova, 86(3), 252-267 (in Russian).

Horalskyi, L. P., Khomych, V. T., \& Kononskyi, O. I. (2005). Osnovy histolohichnoji tekhniky i morfofunktsionalni metody doslidzhen' u normi ta pry patolohiji [Fundamentals of histological technique and morphofunctional research methods in normal and pathology]. Polissia, Zhytomyr (in Ukrainian).

Joyner, A. L. (1938). A study of the white blood cells of the normal guinea pig. American Joumal of Anatomy, 62(4), 497-450.

Kisera, Y., Martyniv, Y., \& Klishch, I. (2020). Pathomorphological changes in the skin of the guinea pigs in the course of microspores. EUREKA: Health Sciences, 26, 76-84.

Medvedeva, E. A., Medvedev, J. A., Teregulova, G. A., \& Fahretdinova, H. S. (2002). Sovremennye problemy izuchenija zooantroponoznyh dermatomikozov [Modern problems of studying zooanthroponous dermatomycosis]. Problemy Medicinskoj Mikologii, 4(2), 89-95 (in Russian).

Merkulov, G. A. (1969). Kurs patologogistologicheskoj tehniki [Course of pathologichistological technique]. Medicina, Lvov (in Russian).

Moriello, K. A., Coyner, K., Paterson, S., \& Mignon, B. (2017). Diagnosis and treatment of dermatophytosis in dogs and cats. Clinical Consensus Guidelines of the World Association for Veterinary Dermatology. Veterinary Dermatology, 28(3), 266-268.

Novoselov, V. S., \& Novoselov, A. V. (2004). Novye aspekty v probleme vybora sovremennogo antimikotika [New aspects in the problem of choosing a modern antimycotic]. Russkij Medicinskij Zhurnal, 12(18), 47-51 (in Russian).

Pasquetti, M., Min, A. R. M., Scacchetti, S., Dogliero, A., \& Peano, A. (2017). Infection by Microsporum canis in paediatric patients: A veterinary perspective. Veterinary Sciences, 4(3), 46 . 
Pototskyi, M. K. (2000). Dermatomikozy [Dermatomycoses]. Veterynama Medytsyna Ukrainy, 11, 20 (in Ukrainian).

Smith, E. B. A. (1947). Certain characteristics of the leukocytes of guinea pig blood with particular reference to the kurloff body. Blood, 2(1), 125-141.

Subelj, M., Marinko, J. S., \& Učakar, V. (2014). An outbreak of Microsporum canis in two elementary schools in a rural area around the capital city of Slovenia, 2012. Epidemiology and Infection, 142(12), 2662-2666.
Vlislo, V. V. (2012). Laboratomi metody doslidzhen u biolohii, tvarynnytstvi ta veterynarniy medytsyni [Laboratory methods of research in biology, animal husbandry and veterinary medicine]. Spolom, Lviv (in Ukrainian).

Yakobysiak, M. (2004). Imunolohiia [Immunology]. Nova Knyha, Vinnytsia (in Ukrainian).

Zimmerman, K., Moore, D. M., \& Smith, S. A. (2015). Hematological assessment in pet guinea pigs (Cavia porcellus): Blood sample collection and blood cell identification. Veterinary Clinics of North America: Exotic Animal Practice, 18(1), 33-40. 